\title{
The syntax and prosody of focus in Northern Amis (Formosan)
}

\author{
Isabelle Bril" \& Stavros Skopeteas**
}

\section{Introduction}

Northern Amis is one of the fourteen surviving Austronesian languages spoken in Taiwan. Amis has four distinct dialects spoken in an area stretching along the east coast from north to south. The present analysis is based on Bril's corpus collected during extensive fieldwork among native speakers of the northern variety of Amis. ${ }^{1}$ As a follow-up to Bril's analysis of the morphosyntactic structure of Information Structure in Northern Amis (2016), this article presents new insights on the hierarchy between clefted core and non-core arguments (Section 3.1), as well as on focus by emphatic lengthening (Section 3.3). It also elaborates on the pragmatic role of the quotative verb $s a$ and the similative verb han as evidential or assertion strengthening foci (Section 3.2). Furthermore, this article contains a prosodic analysis of the focus constructions examining the question whether the expression of focus in these constructions is reflected in particular intonational properties (Section 4).

The article is structured as follows. Section 2 introduces the necessary background on phonological and morphosyntactic properties of Amis. Section 3 analyzes the various types of focus constructions and Section 4 presents a prosodic analysis of these constructions. Section 5 concludes.

\section{Background information}

\subsection{Phonological properties}

Amis does not have lexical tones nor oral/nasal vowel contrast. Vowel length is not distinctive at the lexical level; lengthening is expressive and often focal (it is marked by a colon $<$ : $>$, see details in Sections 3.3., 4.4.). ${ }^{2}$ Stress is indicated by accentuated vowels like $<$ á $>$.

\footnotetext{
" LACITO, CNRS. Mail: isabelle.bril@cnrs.fr

*** University of Göttingen. Mail: stavros.skopeteas@uni-goettingen.de

${ }^{1}$ This research is supported by the LACITO-CNRS and mostly financed by the research strand 3 "Typology and dynamics of linguistic systems" of the Labex EFL (Empirical Foundations of Linguistics) (ANR-10-LABX-oo83/CGI). Fieldwork was conducted over a period of approximately twelve months in various villages around the city of Hualien (Natauran, Pokpok, Lizaw, Daulik, Ciwidian). Warm thanks are due to all Amis informants and friends for their patient and precious collaboration.

${ }^{2}$ Among other graphic conventions, $<\mathrm{q}>$ stands for the epiglottal stop /₹/, as in butiq [ßutí ${ }^{\mathrm{h}}$ ] 'sleep', <d $>$ stands for [ð], $<$ b $>$ for $[ß],<$ ng $>$ for $[\mathrm{y}],<\mathrm{l}>$ for $/ \mathrm{l} /$ and $[\mathrm{l}]$.
} 
The great majority of bare roots are disyllabic, with CV(C).CVC pattern. All words must have an onset and a coda, but word internally, syllables can be open like ceka [tsə.ká?] "fishbone" or closed like cikcik [tcik.tcík] "slice".

Glottal stops may be phonemic or non-phonemic. Due to the rule of obligatory onset and coda, a light glottal stop occurs before a word-initial vowel and after a word-final vowel, as in adada /aðaðá/ [?ađá?] "sick". This epenthetic glottal insertion is rule-driven, and is not represented in the orthography. A non-phonemic glottal stop also occurs between two adjacent vowels, (i) word internally as in baung [ßa?úp] "bow" (to deity), kaen [ka?ən] "eat", and (ii) at the left or the right edge of lexical or inflected prosodic words, as in ma-abac [ma?aßáts] "covered by water", ka-amu [ka?amú?] "let it be you", awa-ay [?awa?áj] "there is not". On the other hand, the glottal stop is phonemic when the high vowels $/ \mathrm{i}, \mathrm{u} /$ precede another vowel: the phonemic glottal stop then contrasts with homorganic glide insertion, as in li'alac [li?aláts] "cure" vs. liyal "sea", tu'ud [tu?úd] "all" vs. itakuwan "(to) me", tu'as [tu?ás] "old" vs. tuwa "then", cu'ay [tsu?áj] "retaliate" vs. cuwa "where", bu'is [bu?ís] "star" vs. tuwid "sparrow". Many cases of phonemic glottal stops are reflexes of glottal or uvular stops in Proto-Austronesian cognates, for instance PAN *Cuqas > tu?ás "old".

There are no consonant clusters; adjacent consonants belong to different syllables, as in CVC.CVC words such as ahbed [?aћ.ßəð] "chewy", ahcid [?aћ.tcíð] "over-salty", baqdet [ßa?.ðət] "hot", angcuh [?ay.tsoћ] "smell of urine".

Vowels in unstressed (i.e., non-final) syllables are frequently hypoarticulated and often centralized. In word internal position, vowels are frequently syncopated, as in bek(e)luh [ßəkloћ] "stone". Vowel centralization does not normally occur in unstressed monosyllabic prefixes, but vowel centralization and syncope occur in some disyllabic prefixes such as mah $(a)$ kulung [mah.ku.lúy] or mal(e)-cabay "be friends" [mal.tsa.ßáj]. These vowels reappear in careful speech as in [mal .tsa.ßáj]. Suffixes beginning with vowels are syllabified within the $\mathrm{CV}(\mathrm{C})$.CVC template, the last consonant of the root is syllabified as the initial consonant of the following syllable: compare tu'as [tu.Pás] "old", ma-tu'as-ay [ma.tu.Pa.sáj] "old people", and cabay [tsa.báj] "friend", cabay-aw [tsa.ba.yáw] "o friend!".

Primary stress is on the last syllable of Amis words (Edmonson et al. 2005, Bril 2016). Prosodic words contain roots, affixes (including infixes) and functional elements. A fully inflected word makes up a single prosodic unit with final stress assigned from its right edge (generally excluding enclitics, as shown in $(\mathrm{lb})$ where the perfective marker $=t u$ is unstressed). Suffixes always attract stress; compare stress assignment on the root meláw [məláw] "see, look", and on the following affixed words melaw-án [mə.la.wán] "seen", and ma-melaw-án [ma.mə.la.wán] "seen" [AMI-TXT-TAT-o88, AMI-TXT-TAT-o77, AMI-TXT-TAT-O72]. ${ }^{3}$

\footnotetext{
${ }^{3}$ The coding scheme of the references to the corpus contains the following identifiers: (a) Language identifier: AMI- = Amis (ISO 639-3); (b) identifier of the data collection: TXT- $=$ text collection, ELI- = elicited data collection; (c) identifier of the subcollection, i.e., text titles: ADE- = U teker ni Adek (Adek's bow); BUD- = Buduy nu Pangcah; CAB- = Cabay aku; LIS- = U lisin; MAL- = Male-paliw; MUL- = Mulecep ci Sawa; RAM- = Ramud; TAT- $=$ Tatakulaq atu hungti; UNI- = 'uner; URI- = Urip nu Balah; or fieldwork periods: o18- = May 2018 data
} 
(1a)

Ma-sa-ka-ulah-án NAV-SPRL-NFIN-rejoice-LV "He looks very cute."

Ma-sa-ka-ulah-án=tu NAV-SPRL-NFIN-rejoice-LV=PFV "(they) look very pleasant." [AMI-TXT-BUD-o69, oo:04:48] a melaw-án cira. LNK look-LV NOM.3. $\mathrm{SG}^{4}$

a melaw-án. LNK look-LV

Enclitics (such as the perfective marker $=t u$ or the paradigm of enclitic genitive pronouns, like $=a k u$ ) are usually unstressed, unless they are focused. Compare the unstressed genitive pronoun $=a k u$ in (2) and (3) with the stressed focused pronoun =akú in (4). In (4), if the pronoun =aku was not stressed, the stress would then fall on the suffix of pa-pi-hakulung-én=aku. Under focus, bisyllabic enclitics are more prone to stress, as they form a foot of their own. Stress assignment is thus criterial in distinguishing suffixes from enclitics.

$$
\begin{array}{lll}
\text { Tara-án=tu }=\text { aku }^{5} & \text { a } & \text { pa-takíd. } \\
\text { go-LV=PFV }=\text { GEN.1SG } & \text { COMP } & \text { CAUS-offer.libation }
\end{array}
$$

"I go there to offer some wine-offerings." [AMI-TXT-CAB-184, oo:12:40]

$$
\begin{aligned}
& \text { Sá ci iná=aku. } \\
& \text { say PM mother=GEN.ISG } \\
& \text { "My mother said." [AMI-TXT-CAB-o78, oo:05:47] } \\
& \text { Pa-pi-hakulung-en=akú. } \\
& \text { CAUS-NFIN-follow-UV=GEN.1SG } \\
& \text { "I let him attend." [AMI-TXT-CAB-022, oo:01:55] }
\end{aligned}
$$

(4) Pa-pi-hakulung-en=akú.

\subsection{Morphosyntactic properties}

The basic word order is verb/predicate initial. Syntactic functions are marked by three case morphemes prefixed to the article/noun marker $u$ : nominative $k$-, oblique $t$-, genitive $n$ - (marking the agent). There are six voice morphemes, which actually fall into two main alignment patterns. Each voice-marked verb selects a $k$ - marked nominative pivot, the preferred syntactic argument, and an argument structure.

The three basic voice markers are the Actor Voice (AV) mi-, the Non-Actor Voice (NAV) $m a-$, and the Undergoer Voice (UV) $m a-$. As shown in Table 1 , AV $m i$ - and NAV $m a$ - or $<u m>{ }^{6}$ have the same alignment, which could broadly be

collection; o16- = 2016 data collection (Dawa); (d) finally accompanied by a number referring to the number of sentence in the respective collection.

${ }^{4}$ Abbreviations: ABIL abilitative; ACC accusative; ANAPH anaphoric; ASS assertive; AT actor trigger; ATTEN attenuative; CA- Ca-reduplication; CAUS causative; COMP complementiser; CONEG conegative marker; DET determiner; DEICT deictic; EPIS epistemic; EVID evidential; EXCL exclusive; EXS existential; FR free (pronoun); FUT future; GEN genitive; IDEO ideophone; INCL inclusive; INST.V instrumental voice; LV locative voice; LNK linker ; MODF modifier; NEG negation; NFIN non-finite; NM noun marker; NMZ nominaliser; NOM nominative; OBL oblique; PASS passive; PM personal marker; PFV perfect; PL plural; PAST past; QM question marker; RC relative clause; RED reduplication; SEQ sequential; SG singular; SIM simulative; SPRL superlative; TOP topic.

${ }^{5}$ The full form of the pronoun is numaku: Tara-án=tu numaku a pa-takíd 'I go there to offer some wine-offerings'.

${ }^{6} \mathrm{~A}$ small class of verbs is derived with NAV infix $<u m>\sim<e m>$. 
characterized as accusative/antipassive, with a nominative subject and an oblique theme. The difference between them is that $\mathrm{AV} m i$ - verbs select an actor nominative subject, while NAV $m a$ - verbs select a nonactor/experiencer nominative subject (also denoting the seat of properties). On the other hand, NAV $m a$ - and UV $m a$ - have different argument structures and different alignments. The UV $\mathrm{ma}$ - has a patient nominative subject and a genitive agent, like the UV voice -en. All verb types may be derived by UV -en, but only transitive verbs can be derived with UV $m a-$ (see Bril 2016, 2017 for further differences). The nominative subject of a verb in locative voice -an is a superficially affected patient or experiencer, or a location (in a broad sense), or a noun referring to some atmospheric, natural phenomena.

The other two applicative voices promote an instrument (Inst.V sa-), or a conveyed entity (conveyance voice $s i-$ ) to subject function. Their alignment is otherwise similar to UV, i.e., ergative with an optional genitive Agent. Voice selection varies with verb classes, with telicity and definiteness (Bril 2016).

Table 1: $\quad$ Case marking and alignment system

\begin{tabular}{|c|c|c|}
\hline voice & $\begin{array}{l}\text { semantic role of NOMINATIVE } \\
\text { SUBJECT }\end{array}$ & argument structure \\
\hline$m i-\mathrm{AV}$ & actor & NOM/ABS; OBL theme \\
\hline$m a-\mathrm{NAV}$ & non-actor & $k-\quad t-$ \\
\hline$m a-\mathrm{UV}$ & patient & \multirow{5}{*}{$\begin{array}{cr}\text { NOM/ABS; GEN agent } \\
k-\end{array}$} \\
\hline -en UV & patient & \\
\hline -an Loc.V & $\begin{array}{l}\text { superficially affected patient } \\
\text { or location }\end{array}$ & \\
\hline$s a$ - Inst.V & instrument & \\
\hline$s i-\mathrm{CV}$ & conveyed entity & \\
\hline
\end{tabular}

Some verbs only occur as AV $m i$ - verbs denoting activities or accomplishments, others are NAV $m a-($ a few infixed $<u m>)$ verbs denoting experiencer, non-actor oriented events, position and motion, as well as states and psych states, properties, and cognition (ma-banaq "know"). Some verb stems strictly belong to one class (either AV mi- or NAV $m a-$ ), others allow both with different meanings, like mi-araw "watch" and ma-araw "see"; mingata "draw near, approach" and ma-ngata "be close". A third class -the bare $\varnothing$-stem class- denotes states and adjectival properties and carries no voice marker; it also includes a few deictic motion verbs (tayni "come, tayra "go").

Telicity and definiteness are in close relation. AV mi- is neutral in relation to telicity and definiteness, it is compatible with atelic activities or telic accomplishments, depending on aspect marking, and with \pm definite $t-u$ themes. UV $m a$ - and UV -en, on the other hand, refer to achievements and must have a definite, or at least specific, patient as their nominative subject. Compare the referentiality of the objects of AV mi- in (5a) and (6a) with the referentiality of the objects of UV in (5b-c) and (6b).

(5a) Mi-sangaq cira $\mathrm{t}-\mathrm{u}$ lunan.

"He's building a/the boat."

$\begin{array}{lllll}\text { (5b) } & \text { Ma-sangaq }(=\text { tu }) & \text { n-ira } & \text { k-u } & \text { lunan. } \\ & \text { UV-make }(=\text { PFV }) & \text { GEN-3SG } & \text { NOM-NM } & \text { boat }\end{array}$

"He built the boat." 


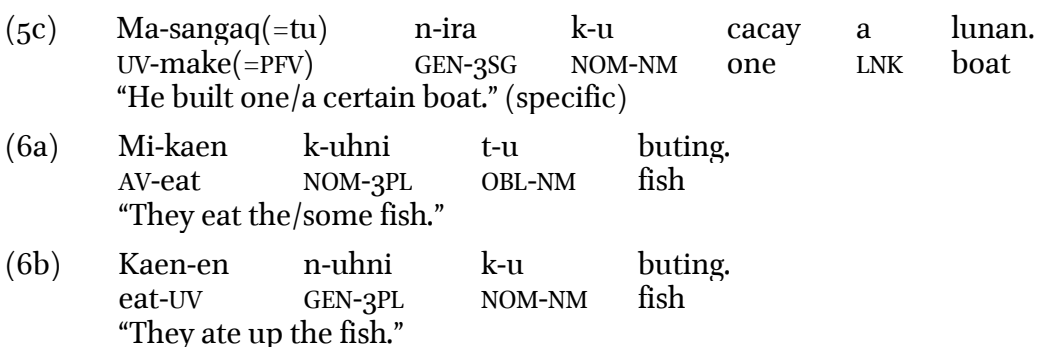

UV -en $n^{7}$ occurs on all verb classes in declarative, imperative and hortative clauses; the genitive agent of UV -en constructions must be animate and intentional. By contrast, UV $m a$ - constructions are restricted to declarative sentences without animacy or intentionality restrictions on the agent. In UV $m a$ - and -en constructions, the agent is optionally expressed. UV -en denotes intentional achievements on fully affected patients, while UV $m a$ - tends to refer to the resulting state of some \pm intentional process or event.

To sum up, the choice of nominative subject varies with verb classes, with valency, with telicity, as well as with affectedness, definiteness or specificity of the patient. The voice system thus offers alternative ways of encoding grammatical relations by selecting a preferred syntactic argument with a given semantic role as the nominative subject. These grammatical relations follow a bipartite alignment.

The following section will show that though voice selection may react to information structure, in particular to the syntactic restructuring triggered by clefted foci, yet, voice is not primarily a means for encoding information structure. Information structure itself is encoded by specific constructions and by various morphosyntactic and prosodic features.

\section{Information structure}

The morphosyntactic encoding of various IS categories (topics, clefts, evidential foci) has been in part analyzed in Bril (2016); the present article briefly presents the main characteristics of left-dislocated topics, and it concentrates on various types of focus constructions, starting with clefted narrow foci (section 3.1). The pragmatic role of quotative sa and similative han as focus markers and assertion strengthening devices is discussed in section 3.2. Emphatic lengthening is introduced in section 3.3 .

Topics constitute a referential frame about which the comment is predicated (Lambrecht 1994). The morphosyntactic and prosodic features of left-dislocated topics in Amis (whether aboutness topics or frame-setting topics) are analyzed in Bril (2016:457-464) and will not be repeated here in detail. Let it just be stated that, in Amis, left-dislocated topics are definite, referential entities marked by an optional topic marker $i$ (ri) and delimited from the comment with an intonational break (associated with a high boundary tone and generally with a pause). By contrast with left-dislocated topics, clefted foci are part of the intonational phrase of the core clause and are not followed by a pause. Compare the declarative clause in (7a) with the

\footnotetext{
${ }^{7}$ Reconstructed by Wolff as PAN *-en patient voice (1973: 73).
} 
left-dislocated topic in $(7 \mathrm{~b})$; as shown in $(7 \mathrm{~b})$, left-dislocated topics are unmarked for case.

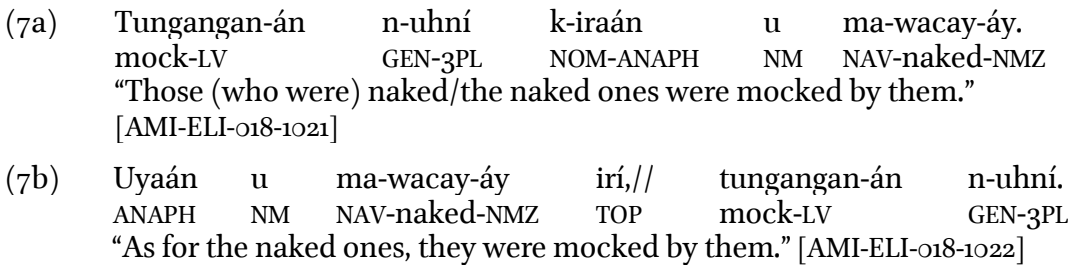

Besides, by contrast with clefted foci, left-dislocated topics are not in the scope of illocutionary force operators, they are neither questioned, nor negated. They are also independent from any syntactic pivot constraint in the voice system, unlike clefted foci which trigger voice shifts (as shown in section 3.1).

\subsection{Cleft constructions}

Focus constructions comprise an asserted restrictor (the focus, which saturates a variable) and the presuppositional content (Krifka 2007). The focus is "the pragmatically non-recoverable element in an utterance (i.e., the assertion)" (Lambrecht 1994: 207).

Two types of focus are usually distinguished: new information focus and contrastive focus. New information focus is typically found as an answer to constituent questions and identifies a variable that satisfies a predication. Contrastive focus, on the other hand, identifies a variable exhaustively (Van Valin 2005).

In Amis, both types of focus are expressed by cleft constructions. Cleft constructions hinge on the partition between assertion and presupposition. The constructions involve extraction of the focused phrase, thus triggering a change of word order and some constraints on voice marking. Hence, cleft constructions are an instance of focus ex situ, while the constructions that are presented in the next sections are instances of focus in situ (quotative $s a$ and similative han in section 3.2 , as well as lengthening as an emphatic focal device in section 3.3).

In Amis, cleft constructions generally express narrow focus, restricted to a single constituent (van Valin, 2005: 69-70). The clefted constituent contains the asserted information and falls within the scope of illocutionary markers (i.e., can be negated or questioned), while the complement to the clefted constituent contains the presupposed information.

The clefted phrase stands in clause initial position, it is predicative and makes up the asserted variable, while the presupposition is expressed either by a headless relative clause (RC) or by a complement clause, depending on the properties of the clefted phrase (core vs. non-core or peripheral arguments). Core and peripheral arguments are thus clefted with radically different constructions, pointing to a hierarchy between them.

Clefted core arguments must be the syntactic, nominative pivot of the RC containing the presupposition, while clefted peripheral arguments, i.e., agents, some non-core oblique arguments, prepositional arguments and 
adjuncts, trigger a clause marked by the complementizer $a[a$ COMP $]$ without any voice indexation. These constructions are discussed in the following.

A well-known constraint on extraction in Formosan and Philippine type languages is that only nominative pivots/subjects can be extracted and relativized (Keenan \& Comrie 1977, 1979). Thus, in order to be clefted, core arguments (i.e., Actor, Patient), as well as instruments and locations, must become the syntactic nominative pivots/subjects of the verb in the presupposition; this is done by means of voice shifts which are presented below.

The semantic roles of clefted core arguments must be co-indexed by the matching voice in the $\mathrm{RC}$ containing the presupposition. A clefted actor thus triggers AV, a clefted patient triggers UV (undergoer voice), a superficially affected clefted patient triggers Locative Voice, a clefted instrument triggers Instrument Voice, a clefted transferred entity triggers Conveyance Voice, etc.

\section{A. Clefted core arguments}

Core arguments include (i) actor subjects of AV mi- verbs, (ii) experiencer subjects of NAV ma- verbs (Non-Actor Voice), (iii) patient subjects of UV maverbs and UV -en verbs, as well as (iv) some oblique, definite themes of AV $m i$ - verbs, and (v) some oblique themes of NAV $m a$ - verbs expressing cognition, affect, interpersonal relations.

When clefted, these core arguments are predicative and their nominative argument is a headless relative clause $[k-u \mathrm{RC}]$ containing the presupposition as shown below.

- We start with clefted Actor constructions. Example (8a) is a declarative sentence with an AV mi-verb, a nominative Actor and an oblique theme. Sentence (8b) displays a narrow clefted Actor construction: the clefted Actor u ma-tuas-ay is predicative, it is marked as past by $n a$, the headless restrictive $\mathrm{RC}$ containing the presupposition stands as its nominative argument marked by $k-u$. Since the clefted argument is the Actor, the verb in the $\mathrm{RC}$ retains its $\mathrm{AV} m i$ - marking, with a less finite, gerund form ( $m i$ diput-áy), which has an oblique argument (itakuwanán).

(8a) Na=mi-dipút $\quad$ k-u ma-tuas-áy itakuwán PAST=AV-take.care NOM-NM NAV-old-NMZ OBL.1SG "Older people brought me up."

(8b) $\quad \mathrm{Na}=\mathrm{u}$ ma-tuas-áy $\quad \mathrm{k}-\mathrm{u} \quad$ mi-diput-áy

PAST=NM NAV-old-NMZ NOM-NM AV-take.care-NMZ

itakuwanán.

OBL.1SG.EMPH

"It was older people who brought me up." (lit. it was older people those who were the caretakers of me) [AMI-ELI-o18-1011]

The information structure partitioning of such constructions are schematically illustrated in the following:

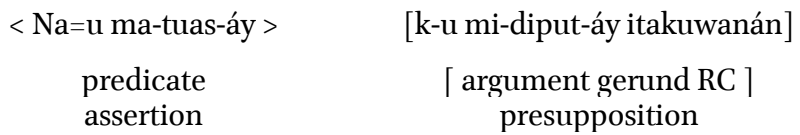


Constituent questions also trigger cleft constructions, with the same constraints on voice. In (9a), the constituent question marker with Actor role (cima) must be clefted. The answer in ( $9 \mathrm{~b})$ is a new information focus displaying the same pattern, with a clefted Actor and a [k-u RC] with an AV gerund verb form (mi-duka-áy "wound-er").

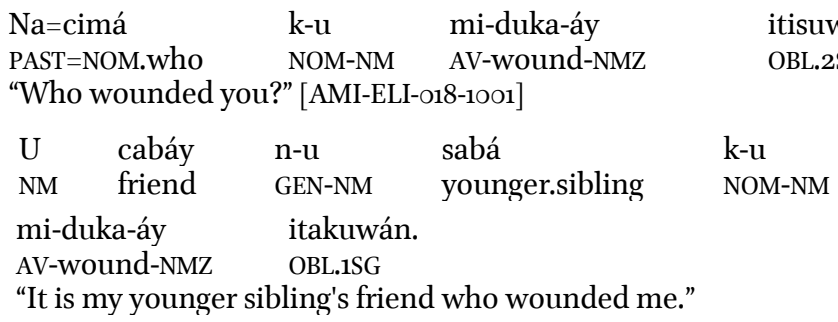

- Clefted patients of UV $m a$ - and UV -en constructions trigger obligatory Undergoer Voice (UV) in the $k-u$ RC as in (1ob); compare with the UV declarative sentence (10a).

$\begin{array}{lllll}\text { (10a) Kaen-en } & \text { n-uhni } & \text { k-u } & \text { buting. } \\ & \text { eat-UV } & \text { GEN-3PL } & \text { NOM-NM } & \text { fish }\end{array}$ "They ate the fish."

(1ob) U buting k-u kaen-en n-uhni. NM fish NOM-NM eat-UV GEN-3PL "It's fish (that) they ate." (lit. It's fish that was eaten by them)

The oblique theme of an AV mi- construction such as (10c) cannot be clefted with an AV mi-construction, thus (1od) is ungrammatical. When clefted, and provided it is definite, it triggers the UV construction in (1ob).

$\begin{array}{llllc}\text { (1oc) } \begin{array}{l}\text { Mi-kaen } \\ \text { AV-eat } \\ \text { "They eat the/some fish." } \\ \text { NOM-3PL }\end{array} & \begin{array}{l}\text { t-u } \\ \text { OBL-NM }\end{array} & \begin{array}{l}\text { buting. } \\ \text { fish }\end{array} \\ \text { (1od) } & \text { *U buting } \quad \text { k-u mi-kaen } & \text { n-uhni. }\end{array}$

Clefted oblique $t-u$ themes of AV mi-verbs and of NAV $m a$-verbs can be treated as core or as non-core arguments depending on (i) telicity, degree of affectedness, and (ii) definiteness of the patient/theme. When they are core arguments, they are clefted with a $[k-u \mathrm{RC}]$ (giving them the pivot function in the $\mathrm{RC}$ ) and with UV -en or LV -an verb forms. When they are non-core arguments, they trigger [ $a$ COMP] clauses (analysed in section 3.1, subsection B).

Oblique themes of AV mi-verbs behave as core arguments when they are specific or definite, and when the mi- verb refers to some activity carried out on a theme/patient. When clefted, these oblique themes trigger a $[k-u \mathrm{RC}]$ and are co-indexed either by UV -en, or by LV -an verb forms if they are superficially affected, i.e., with verbs like "laugh at, bark at, yell at" (see (12)).

Compare the declarative construction in (11a) with the clefts in (11b-c). The interrogative word referring to the theme/patient triggers UV -en in the RC in (11b), as does the cleft theme/patient in (11c). 


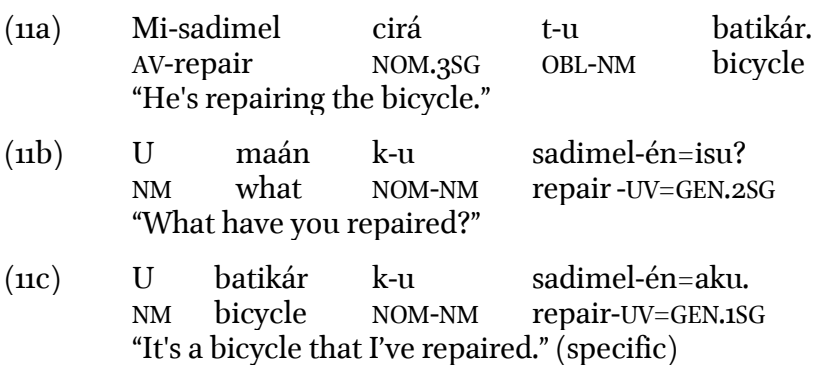

The verb mi-tungangan "mock" in (12a) has an oblique theme $t$ - $u$ mawacay-áy; when clefted as narrow focus, in (12b), it triggers the LV -an verb form in the $[k-u \mathrm{RC}]$. A cleft theme together with AV construction is ungrammatical; see (12c). Compare with the declarative clause in LV construction in (12d).

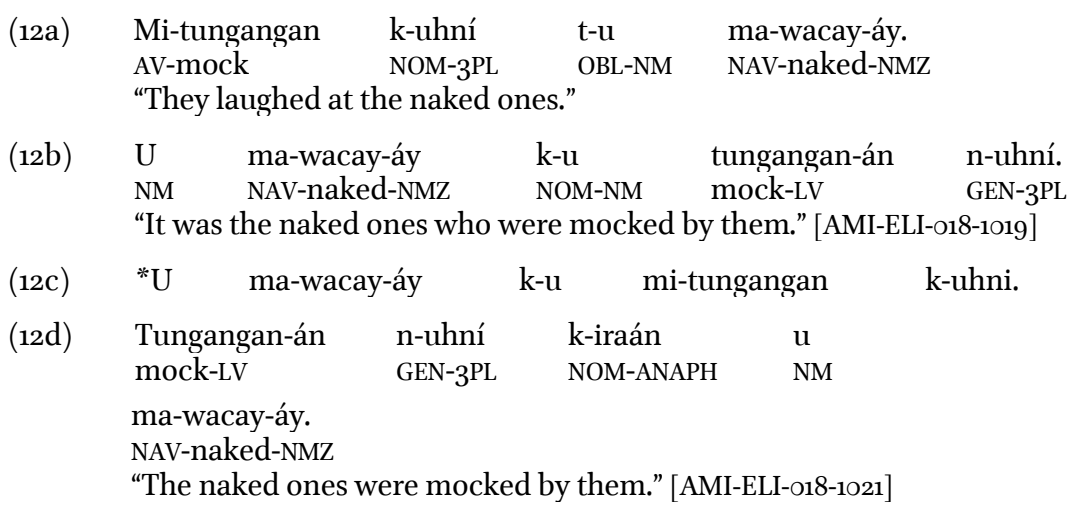

The sentence in (13a) is a negative declarative sentence with NAV marked by infix $<e m>$, with a nominative Actor $(k-a k u)$ and a theme turun atu hemáy. When clefted as in $(13 b)$, the complex $\mathrm{NP}<u$ ni-sabel-án $t$-u daténg a ca:cáy > "only cooked vegetables" triggers obligatory UV -en in the [ $k-u \mathrm{RC}]$ construction. Note that the clefted patient is modified by the numeral cacay "one", which acts as a restrictive focus marker "only" and undergoes emphatic lengthening (ca:cáy), (see sections 3.3 and 4.4).

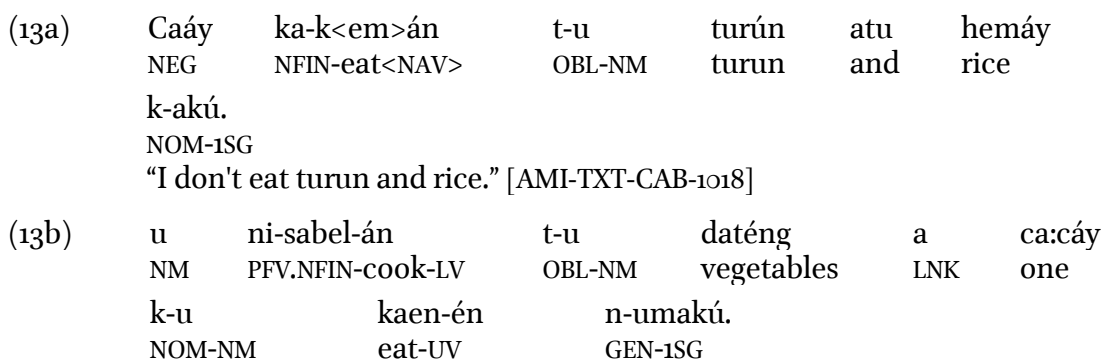

"What I eat is ONLY cooked vegetables." (lit. it's cooked vegetables ONLY that I eat) [AMI-ELI-018-1005] 
The oblique patient/theme of NAV $m a$-verbs (of experience, cognition, affect) behave similarly. These verbs have a nominative experiencer and a superficially affected oblique patient/theme. When clefted, these oblique themes also trigger a $[k-u \mathrm{RC}]$ with $\mathrm{UV}$-en or with $\mathrm{LV}$-an verb forms as in (14b-c); compare with the declarative sentence in (14a).

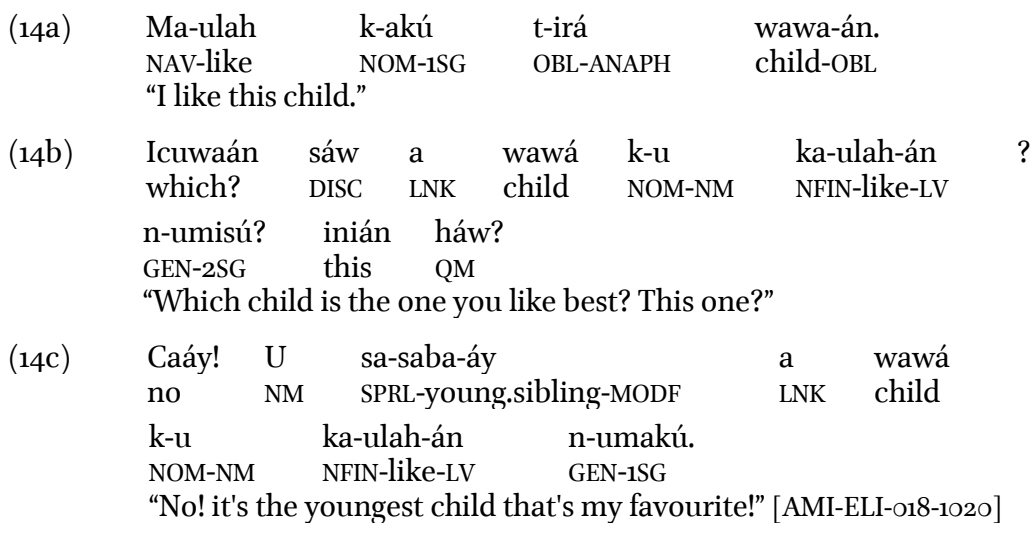

- Instruments and location NPs may also be clefted as core arguments with the $[k-u \mathrm{RC}]$ construction and are co-indexed by the matching Instrument or Locative Voice on the verb in the $k-u$ RC. This construction is illustrated for instruments: sentence (15a) is a declarative construction with an instrument (puut) as nominative pivot, and an oblique patient/object; compare with the clefted instrument in $(15 \mathrm{~b})$.

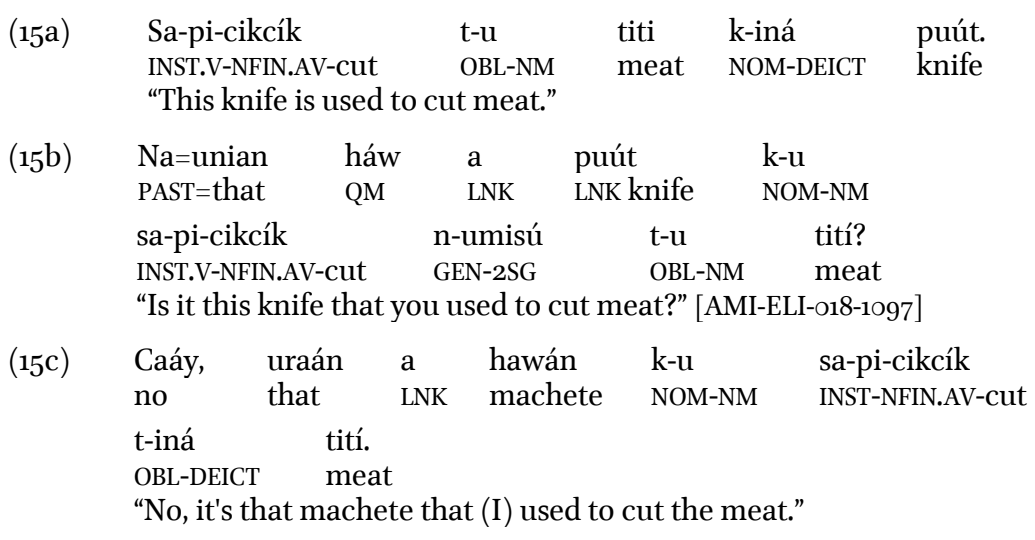

To sum up, all arguments can be clefted, but the constructions of clefted oblique arguments differ, depending on their status as core vs. non-core arguments. Clefted oblique core arguments display the constraint on extraction, their semantic role must be co-indexed by the matching voice on the verbs in the $k-u$ RC. Non-core oblique arguments are clefted with $a$ COMP constructions. 


\section{B. Clefted non-core arguments}

We now turn to various types of non-core, peripheral arguments which are clefted with a COMP constructions without voice indexation. Among them are (i) some oblique themes of a subclass of AV mi- verbs and of NAV maverbs which are treated as non-core; (ii) the agents of UV constructions and of the applicative voice constructions; (iii) the prepositional arguments of three-place AV mi-verbs expressing destination or source (such as "borrow from, buy from"), and (iv) adjuncts. Each case will be discussed briefly (see Bril 2016 for details).

- We start with the oblique themes of a subclass of AV mi-verbs such as "pay a visit, yell at, bark at", and a subclass of NAV $m a$ - psych or experiencer verbs like "fear, feel, like, want", whose oblique themes may be treated as core or non-core. If treated as non-core arguments, they are clefted with $[a$ COMP] constructions without voice indexing. Non-core oblique arguments are often indefinite and superficially affected, especially with verb forms referring to ongoing, atelic processes.

Compare the declarative sentence in AV verb form in (16a) which refers to an ongoing process, with the clefted non-core oblique argument in (16b) which is non-referentially anchored for the speaker. These non-core oblique arguments (and only them) may be questioned in situ, but only for confirmative purposes; see (16d-e). On the other hand, if the process is completed and if the clefted oblique argument is referential, definite as in (16f), it is then marked as a core argument with a [k-u RC] construction and voice co-indexation; it is then the pivot of the $\mathrm{UV}$-en verb.

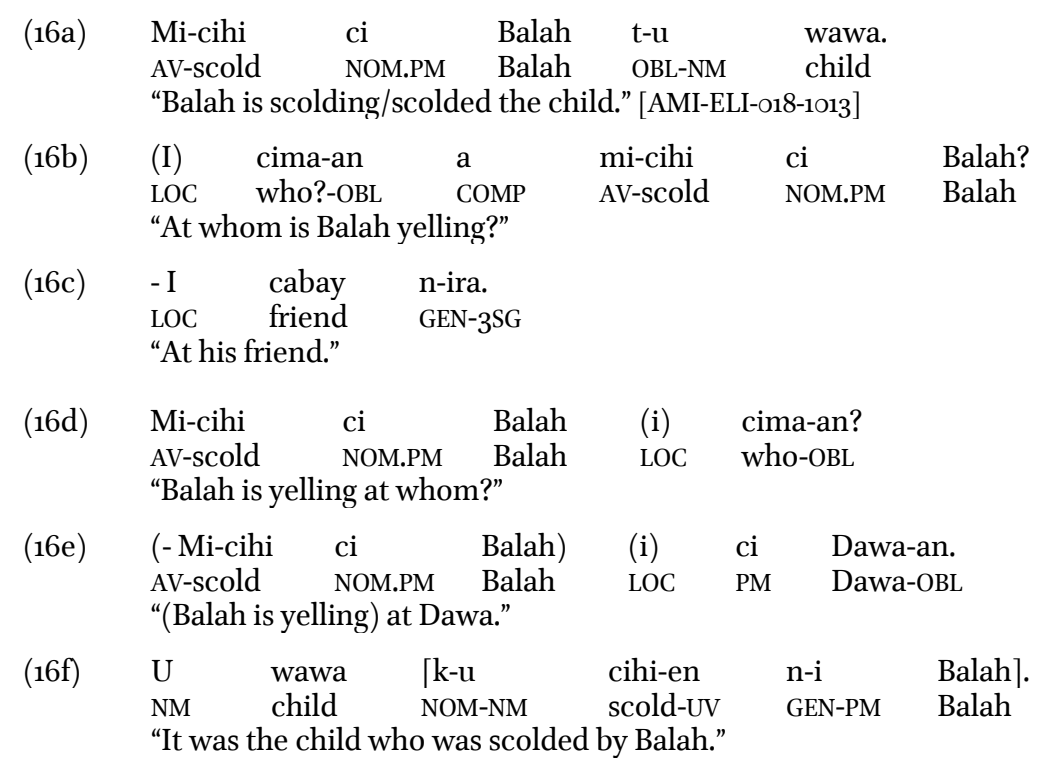

- Agents are not indexed in the verbal voice system; they are non-pivot arguments occurring in transitive UV ma- and UV -en constructions (17a), and in applicative voices (locative, instrumental, conveyance). 
Compare the declarative sentence in (17a) with a verb in UV -en form. Interrogative $(17 \mathrm{~b})$ has a clefted interrogative word $n$-ima referring to the Agent and triggering an $[a \mathrm{COMP}]$ with a non-finite verb form, marked by the perfective nominalizing prefix $n i$-. In a cleft construction such as $(17 \mathrm{~b})$, a finite UV verb form such as cihi-(e)n is disallowed ["na u n-ima a cihi-en k-iya wawa?]. The argument indexed by the LV verb form ni-cihi-an is the nominative undergoer pivot kira wawa "that child".

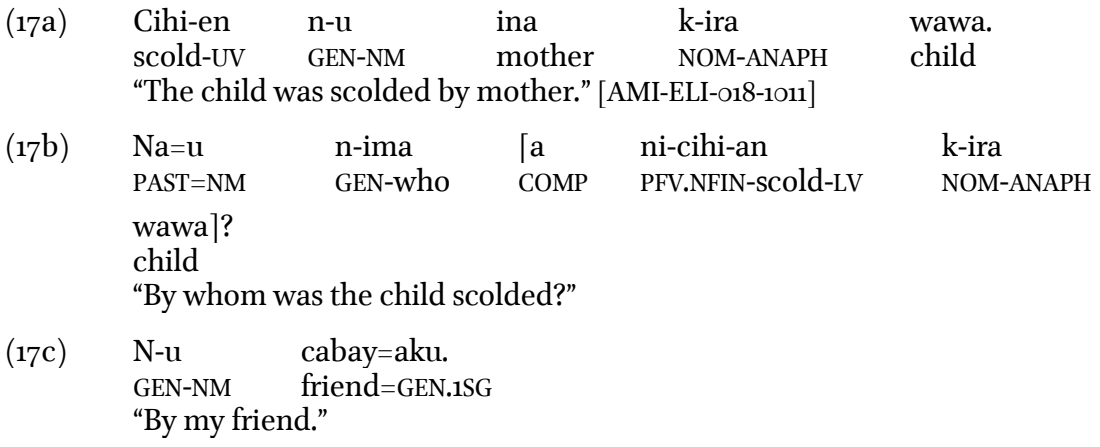

LV indexing is typical of superficially affected patients. However, the preferred construction is a clefted Actor with a $[k-u \mathrm{RC}]$ construction and AV indexing on the nominalized verb as in (18a). The in situ interrogative construction with $\mathrm{LV}$ co-indexing on the verb $(18 \mathrm{~b})$ is restricted to confirmative questions.

$\begin{array}{lllll}\text { (18a) } & \text { Cima } \quad \text { [k-u } & \text { mi-cihi-ay } & \text { t-ira } & \text { wawa]? } \\ \text { who? NOM-NM } & \text { AV-scold-NMZ } & \text { OBL-ANAPH } & \text { child } \\ \text { "Who scolded the child?" (lit. who is the scolder of the child?) }\end{array}$

A similar preference for a clefted Actor with a $[k-u \mathrm{RC}]$ construction and AV indexing on the verb, rather than a clefted Agent of a LV -an or a UV -en construction is shown in (19b). The declarative sentence in (19a) has a patient nominative pivot (Sawa), a verb in LV -an and a genitive agent $(n-u \ldots$ Taluku). But the cleft construction in (19b) shifts to the preferred AV construction, with a clefted Actor (the Taroko people) indexed by an AV verb form in the $[k-u \mathrm{RC}]$ (rather than a clefted Agent heading an [a COMP] construction).

$\begin{array}{lllll}\text { (19a) Lepel-án ci } & \text { Sawá } & \text { n-u } & {[\mathrm{i}} \\ \text { catch-LV NOM.PM } & \text { Sawa } & \text { GEN-NM } & \text { LOC } \\ \text { sa-amis-an-áy } & \text { a] } & \text { Talukú. } \\ \text { DIR-north-LOC-MODF } & \text { LNK } & \text { Taroko } \\ \text { "The Taroko to the north had taken Sawa away." [AMI-ELI-o18- } \\ \text { 1022/-1023] }\end{array}$


$(19 b)$

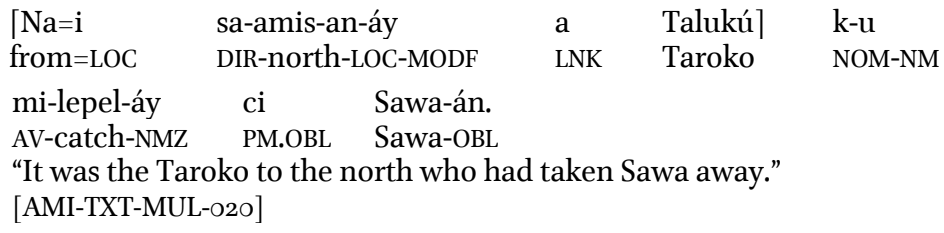

- Oblique non-core arguments of three-place AV mi-verb forms behave in a similar way, as illustrated by verbs expressing destination ("give", "sell") or source (such as "borrow from", "buy from", "learn from"). Compare the declarative sentence with AV construction (20a), with the cleft construction (2ob) in which the clefted source NP phrase triggers an $[a$ COMP] construction and no voice indexation.

$\begin{array}{lllllll}\text { (20a) Mi-nanám } & \text { k-akú } & \text { t-u } & \text { suwál } & \text { n-u } & \begin{array}{l}\text { Pangcáh } \\ \text { Amis }\end{array} \\ \text { AV-learn } & \text { NOM-1SG } & \text { OBL-NM language } & \text { GEN-NM } & \text { Amán. } \\ \text { i ci } & \text { ama-án. } & & \\ \text { LOC PM } \quad \text { father-OBL } & & & \\ \text { "I learnt the Amis language from my father." [AMI-ELI-o18-1017/-1018] }\end{array}$

(2ob) $\quad[\mathrm{Na}=\mathrm{i} \quad$ ci ama-án $\rceil$ k-akú a mi-nanám PAST=LOC PM father-OBL NOM-1SG COMP AV-learn

t-u suwál n-u Pangcáh.

OBL-NM language GEN-NM Amis

"It was from my father that I learned the Amis language."

- Clefted place and time adjuncts also trigger [a COMP] clauses and no voice indexing. Compare the question with a clefted place adjunct ( $i$ Kalingko) in (21a), with the declarative sentence in (21b) and the plain question in (21c).

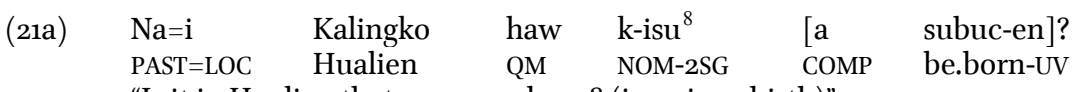
"Is it in Hualien that you were born? (i.e., given birth)"

(21b) Subuc-en k-aku i Gilang. be.born-UV NOM-1SG LOC Yilan

"I was born in Yilan."

\begin{tabular}{|c|c|c|c|c|}
\hline & $\begin{array}{l}\mathrm{Na}=\text { subuc-en } \\
\mathrm{PAST}=\text { be.born-UV }\end{array}$ & $\begin{array}{l}\text { haw } \\
\text { QM }\end{array}$ & $\begin{array}{l}\text { k-isu } \\
\text { NOM-2SG }\end{array}$ & $\begin{array}{l}\mathrm{i} \\
\mathrm{LOC}\end{array}$ \\
\hline
\end{tabular}

\subsection{The pragmatic role of quotative sa and similative han as focus markers}

The similative verb han "be so/do so" and the quotative verb $s a$, often marked for perfective aspect by $=t u$, are pervasively used as focus markers expressing personal stance and strengthened assertion. In contrast to cleft constructions, these expressions of focus do not involve extraction, nor syntactic

\footnotetext{
${ }^{8} k$-isu is raised from the [a COMP] clause; the alternative construction is: na $i$ Kalingko haw a subuc-en k-isu?
} 
restructuring; the focused constituent occurs in situ under the scope of the focus markers $h a n(=t u)$ and $s a(=t u)$. The focus may be a clause, a verb or a noun phrase in any function (see other examples in (35)).

Just like left-dislocated topics, but unlike clefted foci, focus marked by $h a n(=t u)$ and $s a(=t u)$ only occur in declarative clauses; they do not fall under illocutionary scope, i.e., they are not questioned nor negated. Focus marked by $h a n(=t u)$ and $s a(=t u)$ are very common in story-telling, they sometimes signal "alleged", second-hand information; see (24).

In direct speech and in contexts expressing the speaker's viewpoint, as in (22) and (23), they express the speaker's personal stance in relation to some experienced situation or event.

An important feature is that when $h a n(=t u)$ and $s a(=t u)$ are used as focus markers with scope over a verb as in (22) and (23), they act as substitutes of the AV and UV voices, with their respective alignment patterns: $s a(=t u)$ replaces AV with AV alignment, while han $(=t u)$ replaces $\mathrm{UV}$ with UV alignment. Thus, while voiced affixed verbs are descriptive and pragmatically neutral, verbs under the scope of $h a n(=t u)$ and $s a(=t u)$ express personal stance, strengthened assertion, and alleged information in narratives as in (24) (see their prosodic properties in section 4.3).

In (22a), the verb under focus with $s a$ expresses strengthened assertion, while the declarative sentence with UV $m a$ - in (22b) refers to a state of thing. Example (23) mentions some personal experience with focal strengthening of the verb lusaq "cry". In the narrative context of (24), focal strengthening bears on the whole clause and carries evidential features.

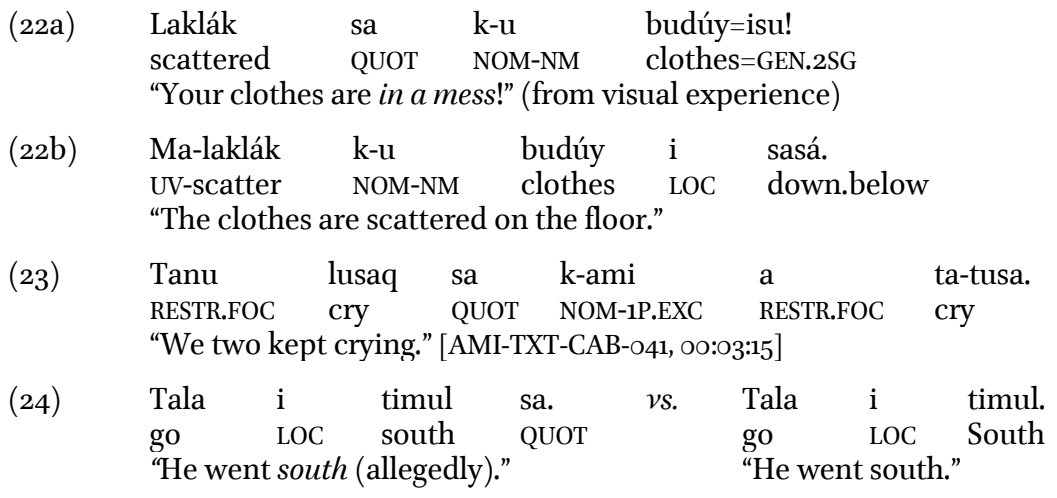

Focal $\operatorname{han}(=t u)$ is also extremely frequent, with similar function. When it has scope over a verb, it occurs in place of a UV verb form and expresses event focus, as in (25a). Compare with the descriptive UV verb form abubu-en in $(b)$.

\begin{tabular}{|c|c|c|c|c|}
\hline$\left(25^{a}\right)$ & $\begin{array}{l}\text { Abubu } \\
\text { hold.in.arms }\end{array}$ & $\begin{array}{l}\text { han }=\mathrm{tu}=\mathrm{aku}, \\
\mathrm{SIM}=\mathrm{PFV}=\mathrm{GEN} .1 \mathrm{SG}\end{array}$ & $\begin{array}{l}\text { "pa-cici } \\
\text { CAUS-insist }\end{array}$ & $\begin{array}{l}\text { a } \\
\text { COMP }\end{array}$ \\
\hline & $\begin{array}{l}\text { mi-sa-keru } \\
\text { AV-do-dance }\end{array}$ & $\begin{array}{ll}\text { k-aku" } & \text { sa! } \\
\text { NOM-1SG } & \text { say }\end{array}$ & & \\
\hline
\end{tabular}


(25b) Abubu-en=aku.

hold.in.arms-UV=GEN.1SG

"I held (him) in my arms."

$\operatorname{Han}(=t u)$ occurs more frequently with verbal focus as in (25a) than with NP focus. However, just as with $s a(=t u)$, the focus may be a noun phrase, as in (26b). Starting from the declarative clause in $(26 \mathrm{a})$ with a nominative actor $k$ $i s u$, an oblique patient $t$ - $u$ atáy and a prepositional argument referring to the beneficiary $i$ t-irá wawa-án, sentence (26b) displays a left-dislocated topic pronoun isu "you", made contrastively focal by han $(=t u)$. The rest of the sentence displays a clefted noun $u$ atáy "liver" co-indexed in the RC construction by the Instr.V $s a$ - as the instrument of the gift.

\begin{tabular}{lclll} 
A=painí & \multicolumn{1}{c}{ - $\mathrm{u}$} & atáy & $\mathrm{i}$ & $\mathrm{t}$-irá \\
FUT=present & OBL-NM & liver & LOC & OBL-ANAPH \\
$\begin{array}{ll}\text { wawa-án } \\
\text { child-OBL }\end{array}$ & k-isú. & & & \\
NOM-2SG & & &
\end{tabular}

"You'll present the liver to the young (girl)." [AMI-ELI-o18-1015]

\begin{tabular}{llllll} 
Isú & hantú, & u & atáy & k-u & sa-painí \\
FR.2SG & SIM.FOC & NM & liver & NOM-NM & INST.V-present \\
i & t-irá & \multicolumn{4}{c}{ wawa-án. } \\
LOC & OBL-ANAPH & child-OBL \\
"As for you, (it)'s the liver that you"ll present to the girl."
\end{tabular}

\subsection{Lengthening and stress shift: a device for emphatic focus}

Emphatic lengthening (marked by <:> or by <:: > if super-long) is another common pragmatic device, which applies in situ to any constituent or any part of the utterance under focus. Lengthening generally applies to the final syllable of the emphasized root. Unlike focus marked by $s a(=t u)$ or $h a n(=t u)$, emphatic lengthening may occur in all clause types (declarative, negative), it may take scope over a left-dislocated topic which is thus focused; see (26b). Its purposes are diverse: example (27a) shows the combination of the assertion strengthening device $s a=t u$ which brings the event under focus, and emphatic lengthening on the verb medu:k which emphasizes the degree of speed. In (27b), emphatic lengthening falls on the verb ma-h(a)kulú:ng and emphasizes the length of the process.

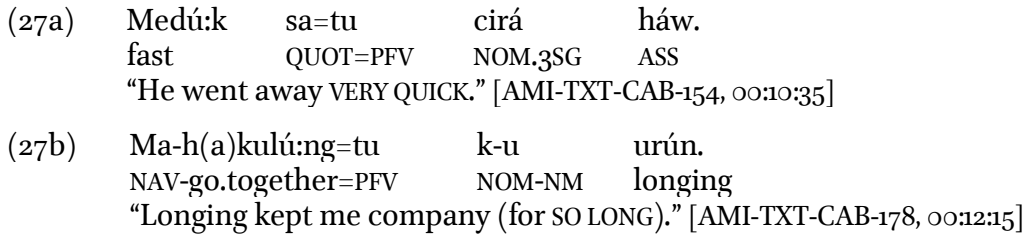

In (28a), emphatic lengthening falls on the superlative adjectival modifier sa-tataá::k-ay, marking degree and contrast. Lengthening of the root's final syllable attracts stress to it, causing some stress shift, as in sa-tataá:k-ay, while in the standard, non-emphatic form in $(28 \mathrm{~b})$, the final syllable of the prosodic word (i.e., the suffix) carries the stress according to rule (sa-tataak-áy). 


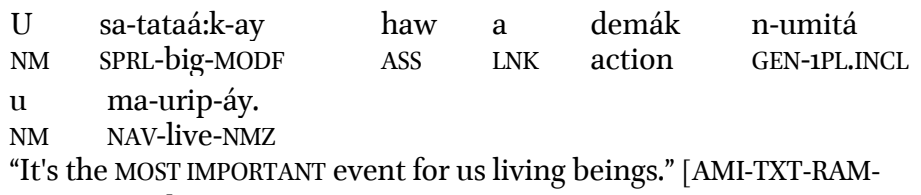

$\begin{array}{lllll}\text { U } & \text { sa-tataak-áy } & \text { a } & \text { demák } & \text { n-umitá... } \\ \text { NM } & \text { SPRL-big-MODF } & \text { LNK } & \text { action } & \text { GEN-1PL.INCL }\end{array}$

"It's the most important event for us..."

Emphatic lengthening also occurs together with CVCV or Careduplication. Stress often, but optionally, shifts to the penultimate syllable. It also expresses emphatic focus, with a variety of contextual meanings, such as reference to a gradual, lengthy process, as in kapaká:pah=tu "it's gradually improving" (from kapáh "good") [AMI-ELI-o16-1053]; imminence, mapatapá:tay "on the verge of dying" (from ma-patáy "die, be dead"); exhaustive quantification, sa remiremi'á:d sa "absolutely every day" (from remi'ád "day") [AMI-TXT-CAB-O26]; high degree, caay ka-ta-tú:dung (NEG NFIN-Ca-fit) "absolutely unfit" [AMI-TXT-ADE-O1O].

In (29a), the numeral cacáy "one" is used as a restrictive focal marker meaning "only one". When it is reduplicated as cacacá:cay "any one at all", it then expresses exhaustive free choice and the lengthened penultimate syllable attracts stress to it (see prosodic properties in section 4.4). Another instance occurs in (ex. 13b) above.

\begin{tabular}{|c|c|c|c|c|}
\hline (29) & $\begin{array}{l}\text { Awaáy } \\
\text { NEG.EXS }\end{array}$ & $\begin{array}{l}\mathrm{k}-\mathrm{u} \\
\mathrm{NOM}-\mathrm{NM}\end{array}$ & $\begin{array}{l}\text { nika-melaw-án=aku } \\
\text { PFV.NFIN-see-LV=GEN.1SG }\end{array}$ & $\begin{array}{l}\mathrm{t}-\mathrm{u} \\
\text { OBL-NM }\end{array}$ \\
\hline & $\begin{array}{l}\text { caca|cá:cay } \\
\text { RED|one }\end{array}$ & $\begin{array}{l}\text { acá } \\
\text { also }\end{array}$ & $\begin{array}{ll}\text { a } & \text { tamdáw. } \\
\text { LNK } & \text { person }\end{array}$ & \\
\hline
\end{tabular}

\section{Prosody of focus constructions}

The preceding sections have presented the morphosyntactic and semantic properties of various focus constructions. The crucial questions are: (a) Is focus associated with a particular prosodic event? (b) Are the constructions presented in section 3 associated with particular prosodic realizations? In order to address these questions, we first outline our basic prosodic assumptions in Section 4.1. With this background, we examine the prosody of the constructions introduced in Section 3, i.e., cleft constructions (Section 4.2), focus markers $s a=t u$, han=tu (Section 4.3), and emphatic lengthening (Section 4.4).

The present account is based on a qualitative inspection of the properties of pitch excursions, pauses and effects on duration, based on single occurrences of focus in our corpus. ${ }^{9}$ Most utterances presented in the following are part of recorded narratives. In some cases, we elicited utterances in isolation in order to observe the prosodic realization of minimal pairs (e.g., simple clauses vs. cleft constructions). If the context was relevant

9 We refrain from analyzing intensity at this stage, since qualitative research cannot realistically manage the huge amount of variation in intensity facts. 
(e.g., for establishing the contextual conditions for a focus domain), we used small conversational contexts that are given in brackets (in English translation); see examples in (33).

\subsection{Basic prosodic properties}

The basic properties of Amis prosody are introduced by means of the utterance in (30), which displays two sentential conjuncts with the same syntactic structure, each containing an initial predicate and a subject.

$$
\begin{aligned}
& \mathrm{Ci} \text { ama=aku ci Buting Sabung, ci } \\
& \text { PM father=GEN.1SG PM Buting Sabung PM } \\
& \text { ina=aku ci Lahuk } u \text { Buting. } \\
& \text { mother=GEN.1SG PM Lahuk NM Buting } \\
& \text { "My father was Buting Sabung, my mother was Lahuk u Buting." } \\
& \text { [AMI-TXT-URI-oO5] }
\end{aligned}
$$

The prosodic realization of this utterance is plotted in Figure 1. The line below the $F_{\mathrm{o}}$ excursion presents tonal events that are defined with reference to levels of prosodic constituency ( $\varphi$ or $\iota)$. Within the framework of autosegmental phonology, we assume two classes of tonal events: events associated with the edges of prosodic constituents, and events associated with stressed syllables (Pierrehumbert 1980:32-47; Ladd 2008:92-104). Two higher layers of prosodic constituency are relevant for our study: intonational phrases and phonological phrases. Intonational phrases (l-phrases) are the highest prosodic entities that encompass clauses, topic phrases and parentheticals (see Selkirk 2011:439, Féry 2017:59ff.). Phonological phrases $(\varphi$-phrases) are immediately contained within intonational phrases and encompass lower syntactic constituents (beyond the clause), e.g., noun phrases, prepositional phrases, verb phrases. The pitch tracks in the following are annotated for the edge tones that are associated with these layers, i.e., phrase tones (associated with the edges of $\varphi$-phrases) and boundary tones (associated with the edges of t-phrases); see Figure 1. The type of prosodic constituent that is associated with an edge tone is given as subscript (following the notation used by Gussenhoven 2004 and Féry 2017).

Figure 1 shows the prosodic realization of sentences with two clausal conjuncts, in order to illustrate the possible contrast between boundary tones. (A canonical V-initial utterance without contrasted counterpart is presented in Figure 2 below.) The two clausal conjuncts in Figure 1 are mapped onto t-phrases, delimited by different boundary tones. The first conjunct is not final within the discourse unit and ends with a continuation rise $\left(\mathrm{H}_{2}\right)$; the second conjunct is final in the discourse unit and ends with a final lowering that is represented by a low target at the right edge of the intonational phrase $\left(\mathrm{L}_{\mathrm{t}}\right.$ ). This pattern is reminiscent of phenomena that are reported for very different languages, final lowering at the end of final declaratives and continuation rise at the right edge of non-final utterances (Gussenhoven 2004:101; Ladd 2008:103-104).

Both l-phrases display a binary internal structure in Figure 1. A first prosodic constituent encompasses the predicate nominal and a second prosodic constituent encompasses the subject. These subconstituents are $\varphi$ phrases, encompassing syntactic constituents that are lower than the clause 
layer. The subconstituents of each t-phrase are separated by a short break. The default contour of $\varphi$-phrases involves a falling contour within the last syllable, which is clearly visible when the right edge of the $\varphi$-phrase does not coincide with the right edge of an t-phrase (in which case the phrase tones are confounded with the boundary tones). The left edge of the $\varphi$-phrase is tonally underspecified; both $\varphi$-phrases show a slight rise up to the H-target at the onset of the last syllable, which is the starting point of the $\varphi$-phrase final falling contour.

Recall that word stress falls on the last syllable in Amis; see Section 2.1. Hence, an alternative analysis would be that the falling contour within the last syllable is a reflex of word stress. However, instances of stress shift show that the fall always takes place within the last syllable and not within the stressed syllable whenever they do not coincide; see, e.g., the falling contour following a stressed prefinal syllable in Figure 7 a below. Hence, the falling contour is associated with the right edge of a $\varphi$-phrase, which is indicated by the notation $\mathrm{H}_{\varphi} \mathrm{L}_{\varphi}$. These falling contours consistently appear in the Amis data unless a higher-level tonal event (a boundary tone) "overwrites" it. Thus, the tonal events at the right edge can be described solely with reference to prosodic constituency (see similar analyses of French and Hindi by Féry 2017:271-281).

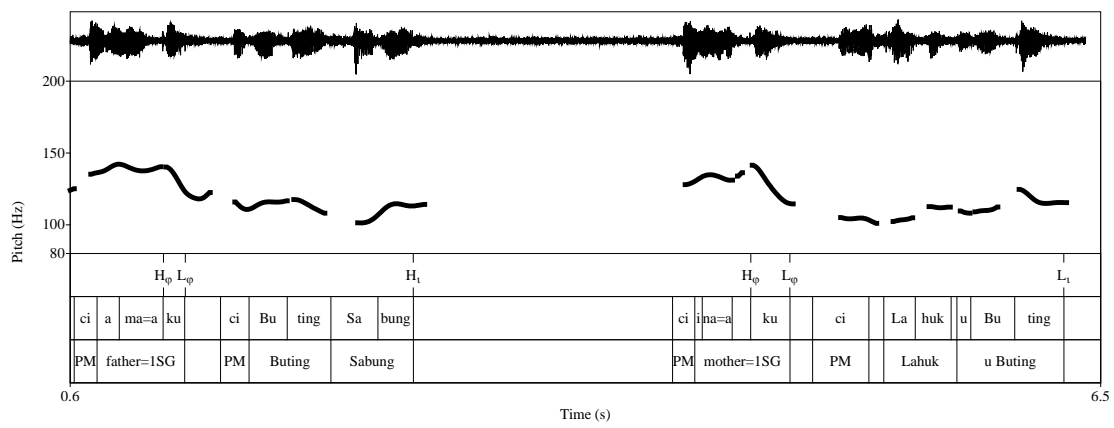

Figure 1: $\quad$ Prosodic structures of Amis

\subsection{Cleft constructions}

The prosodic properties of cleft constructions contain the tonal ingredients that are introduced in Section 4.1. Example (31a) is a canonical declarative sentence with VS order; example (31b) is the corresponding cleft construction: the $\mathrm{S}$ is part of the matrix clause and the verb is nominalized.

(31a) Mi-kutáy=tu ci Cidál. AV-replace $=$ PFV $\quad$ PM Sun "Sun replaced (him)."

(31b) Ci Cidál=tu k-u mi-kutay-áy. PM Sun=PFV NOM-NM AV-replace-NMZ

"It was Sun who was the substitute." [AMI-AMI-TEK-o18]

The prosodic realization of these examples is presented in Figure 2. Crucially, both examples are recorded without context, such that they 
contain prosodic reflexes of the syntactic structure alone. The encompassing t-phrases branch in two $\varphi$-phrases respectively. The right edge of the initial $\varphi$-phrase, which is the $\mathrm{V}$ in (31a) and the subject in (31b), is realized with a steep fall. Similar falling contours are observed in the final $\varphi$-phrases too; the $\mathrm{H}$-targets of these $\varphi$-phrases are downstepped within the domain of the intonational phrase. The H-targets of the $\mathrm{H}_{\varphi} \mathrm{L}_{\varphi}$ phrase tones are consistently aligned with the onset of the last syllable of the respective $\varphi$-phrase in these examples.

The comparison of the examples in Figure 2 reveals that canonical and cleft constructions do not necessarily correspond to different prosodicconstituent structures. Both constructions are characterized by a tonal event delimiting an initial $\varphi$-phrase that encompasses the verb in canonical Vinitial sentences or the clefted constituent in cleft constructions. Hence, the answer to question (b) above (see preliminary remarks in Section 4) is that cleft constructions are not intrinsically associated with a special prosodic realization. If they appear with special prosodic properties in contexts involving focus, then such properties should rather reflect focus and not the syntactic structure itself.

(a) Canonical sentence

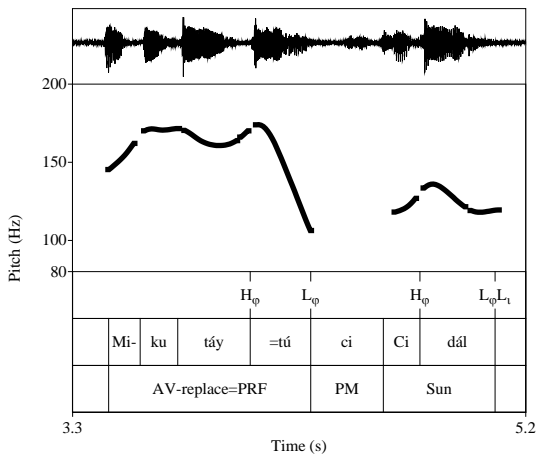

(b) Cleft construction

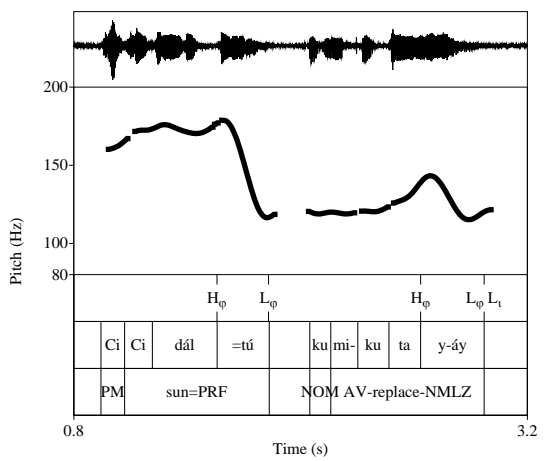

Figure 2: $\quad$ Canonical sentences and cleft constructions [AMI-ELI-o18-109o] ${ }^{10}$

Let's now examine the prosodic realization of cleft constructions in contexts inducing narrow focus on the initial constituent. Focus will be shown to have the following prosodic reflexes: (a) the postfocal domain is (optionally) de-accented; (b) foci are integrated to the prosodic constituent encompassing the predicate; (c) the focused constituent is realized with a sharp rise around the onset of the stressed syllable.

These properties are illustrated by $\left(3^{2}\right)$. The speaker was instructed to pronounce the question-answer pair simulating a natural conversation. The clefted constituent (in the question and answer) is an instrument, triggering a $k-u$ relative clause with instrumental voice (see sections 2.2 and 3.1). The question in (32) sets up the ideal context for postfocal de-accenting. The complement of the focus in the answer is presupposed information that is literally available in the question. In such cases, if the presupposed

\footnotetext{
${ }^{10}$ Glosses are shortened in the pitch tracks for space reasons.
} 
information is not elided, it is expected to be de-accented (see Ladd 2008:231236).

\begin{tabular}{|c|c|c|c|c|c|}
\hline - U & maán & & sa-pa-kaén & n-umisú & $t-u$ \\
\hline & & NOM-NM & INST-CAUS-eat & GEN-2SG & OBL-NM \\
\hline \multicolumn{6}{|c|}{$\begin{array}{l}\text { cabáy? } \\
\text { friend } \\
\text { "What did you give your friend to drink?" (lit. "What is the thing used to } \\
\text { give to drink to the friend by you?") }\end{array}$} \\
\hline - U & qepáh & & sa-pa-kaén & n-umakú & $t-u$ \\
\hline NM & wine & NOM-NM & INST-CAUS-eat & GEN-1SG & OBL-NM \\
\hline
\end{tabular}

The prosodic realization of the answer is shown in Figure 3. The $F_{\circ}$ excursion of the postfocal domain is a low plateau without significant tonal events. Such examples show that postfocal de-accenting is possible in Amis. With respect to phrasing, Figure 3 reveals another property of foci: in contrast to topics, which are very frequently separated by a pause from the comment (Bril 2016), such that the topic and the comment are mapped onto two different t-phrases, cleft constructions make up one single t-phrase. This difference between clause-initial foci and topics has been observed in several $\mathrm{V}$-initial languages (see references in Section 5).

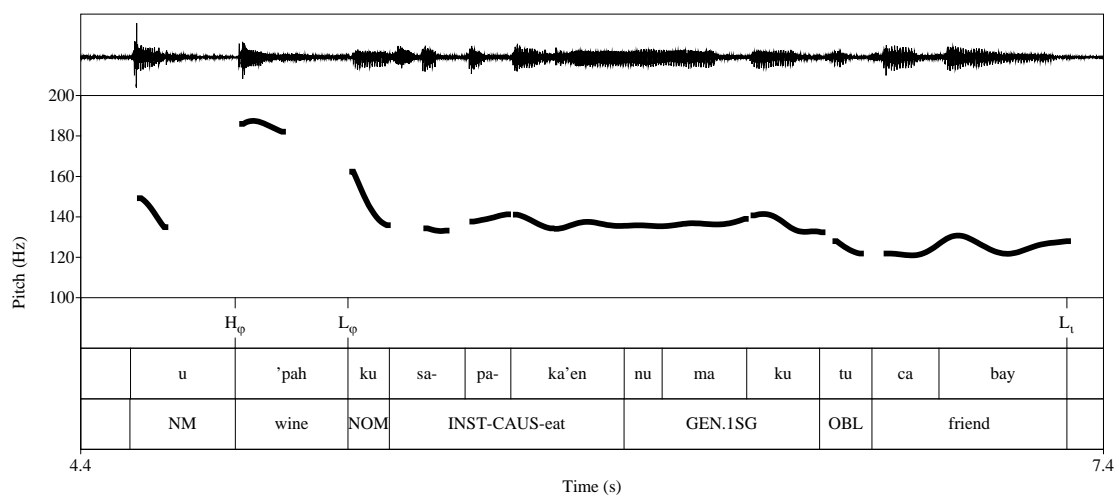

Figure 3: $\quad$ Postfocal de-accenting [AMI-ELI-o18-1091]

The $F_{\text {o }}$ excursion of the clefted constituent in Figure 3 differs from the previous examples. While the $F_{\mathrm{o}}$ excursion of the initial constituents in Figure 1 and Figure 2 starts at a middle range (compared to the $F_{\circ}$ range of the utterance), clauses with narrow foci start with a low $F_{\mathrm{o}}$ and have a sharp rise around the onset of the stressed syllable (see Figure 3). Further examples of this pattern are given in Figure 4, which only displays the clefted constituent and the nominative $k-u$ that belongs to the presupposed RC. The tonal events of the focused constituent are very similar in the four examples. In contrast to the prosody in neutral contexts, these utterances display a sharp rise around the onset of the stressed syllable of the narrow focus. We assume a bi-tonal 
event $\left(\mathrm{L}+\mathrm{H}^{*}\right)$ marking focus, whereby the $\mathrm{H}$-target is associated with the stressed syllable and the leading L-tone is found in the preceding syllable. The view that the L-tone is a low target within the word is motivated by the fact that the $F_{\mathrm{o}}$ excursion of these examples displays an elbow, whose turning point is timed before the onset of the stressed syllable. This analysis is further supported by the examples in Figure $4 b-c$, in which the pitch shows a falling contour towards a low target before the last syllable. Furthermore, the prosodic realization of words with stress shift (see Section 4.4) shows that the rise is not associated with the onset of the last syllable but with the onset of the stressed syllable.

The examples (33a)-(33b) are instances of new information focus, while the example (33c) illustrates contrastive focus (see the focused constituents in figure 4). The tonal realization does not crucially differ between these examples, which does not exclude that there are fine-grained differences between new information and contrastive foci that may be detected in a larger quantitative study. What we conclude at this stage, is that these types of focus are not necessarily associated with different prosodic realizations.

(a)

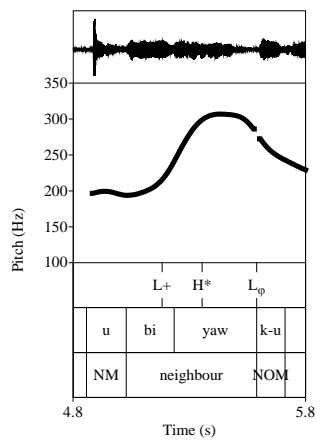

(b)

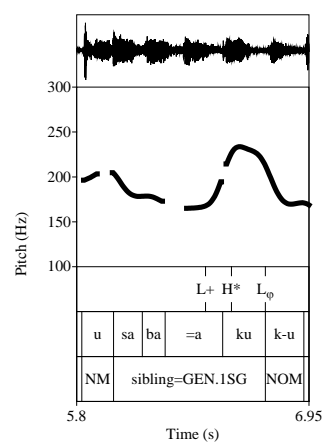

(c)

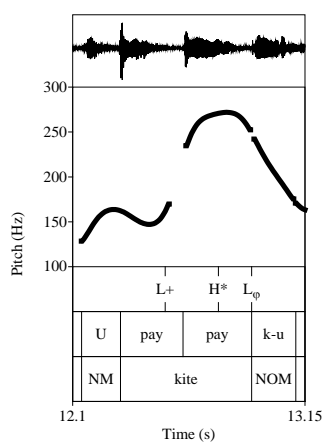

Figure 4: Clefted foci

[Who wounded you?]

$$
\begin{aligned}
& \mathrm{U} \text { biyaw [k-u mi-duka-ay itakuwan]. } \\
& \text { NM neighour NOM-NM AV-wound-NMZ OBL.ISG } \\
& \text { "It is A NEIGHBOUR [the one who wounded me]." [AMI-ELI-o18-1029] }
\end{aligned}
$$

[Was it you who came yesterday? No, it was not me,]

$$
\begin{aligned}
& \mathrm{U} \quad \mathrm{saba}=\mathrm{aku} \quad[\mathrm{k}-\mathrm{u} \text { tayni-ay }] \text {. } \\
& \text { NM younger.sibling=GEN.1S NOM-NM arrive-NMZ } \\
& \text { "It was MY YOUNGER SIBLING [the one who came.]" [AMI-ELI-o18-1049] }
\end{aligned}
$$

(33c) [What is flying in the sky? Is it a bird? No,]

$$
\begin{aligned}
& \text { U paypay [k-u } \quad \text { ma-baher-ay]. } \\
& \text { NM kite NOM-NM NAV-fly-NMZ } \\
& \text { "It is A KITE [the one that's flying]." [AMI-ELI-o18-1056] }
\end{aligned}
$$

In sum, the prosodic constituent structures of cleft constructions and canonical V-initial sentences are similar, with an initial $\varphi$-phrase encompassing the verb (in V-initial sentences) or the clefted constituents (in cleft constructions) and a further $\varphi$-phrase encompassing the remainder of the utterance. A particular prosodic event appears with narrow focus on the clefted constituent, consisting in a sharp rise $\left(\mathrm{L}+\mathrm{H}^{*}\right)$, starting before the onset 
of the stressed syllable and reaching a H-target early within the stress. If this event is associated with focus, it should appear independently of cleft constructions. This possibility is examined in the next section.

\subsection{Constructions with focus markers}

The quotative verb $s a$ - often followed by the perfective enclitic $=t u$ - is used as a focus marker expressing stance and strengthened assertion; see Section 3.2. ${ }^{11}$ Crucially, this marker has scope on its left, i.e., the constituent to the left of $s a$ is in focus. The utterances with $s a(=t u)$ display the characteristic sharp rise within the stressed syllable of the focused constituent, that was observed in Section 4.2 with clefts. The focus marker is phrased together with the focus (in the same $\varphi$-phrase).

Culal sa cira itini. appear QUOT NOM.3SG here

"He suddenly appears here." [AMI-ELI-016-1007]

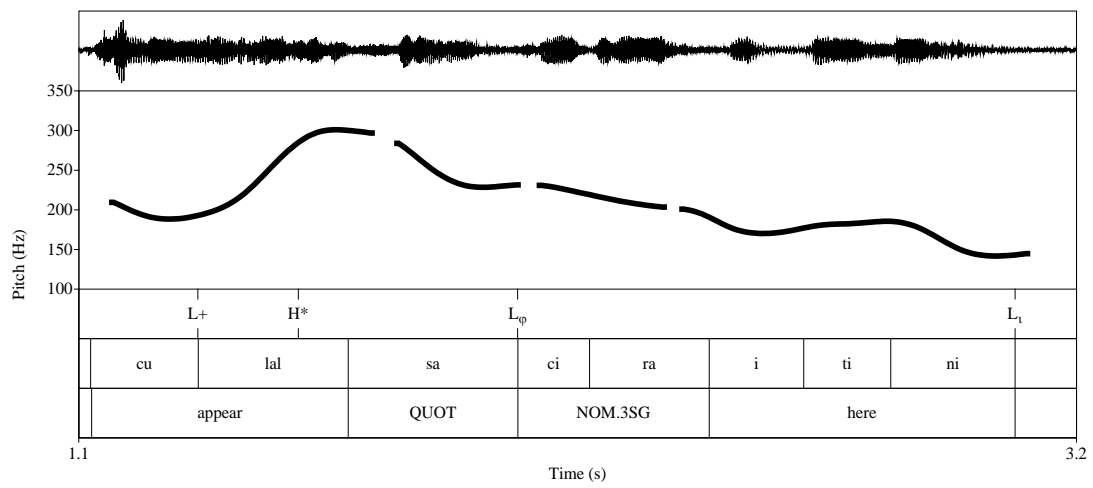

Figure 5: $\quad F_{\mathrm{o}}$ excursion of initial focus with the focus marker sa "QUOT"

Further instances of the focus marker confirm this pattern; see Figure 6. The prosodic realization of these examples is similar to the prosodic realization of narrow focus in clefts (Figure 3 and Figure 4): they all display a sharp rise before the stressed syllable. Figure $6 \mathrm{c}$ is similar to Figure $4 \mathrm{~b}$ : in both cases, the $F_{\mathrm{o}}$ excursion starts with a falling contour targeting a low level before the sharp rise at the onset of the stressed syllable. This data supports the view that the sharp rise around the onset of the stressed syllable is a tonal event that is associated with focus. In (35a), focal strengthening bears on a spatio-temporal noun terung "middle"; in $(35 \mathrm{~b})$ it bears on the deictic pronoun inian:

$$
\begin{array}{lllll}
\text { Terung } & \text { sa=tu } & \text { n-u } & \text { ni-ka-lahuk, } & \text { ira } \\
\text { middle } & \text { QUOT=PFV } & \text { GEN-NM } & \text { PFV.NMZ-NFIN-lunch } & \text { EXS } \\
\text { k-u } & \text { ni-pa-kan } & \text { t-u } & \text { hemay. } & \\
\text { NOM-NM } & \text { PFV.NMZ-CAUS-eat } & \text { OBL-NM } & \text { rice } & \\
\text { "Right at midday }{ }^{12} \text {, there was rice for lunch." } & \text { [AMI-TXT-MAL-o14, oo.o1.45] }
\end{array}
$$

${ }^{\text {I }}$ We concentrate on the prosodic properties of the constructions with the quotative verb $s a$, setting the form han=tu aside for the purposes of the exposition.

${ }^{12}$ The derived noun ni-ka-lahuk (lit. lunch-time) refers to times of day, here midday. 


$\begin{array}{llllll}\text { Inian } & \text { sa=tu } & \text { u } & \text { tadamaan-ay } & \text { a } & \text { lisin. } \\ \text { DEICT.PRO } & \text { QUOT=PFV } & \text { NM } & \text { important-MODF } & \text { LNK } & \text { festival } \\ \text { "THIS is a very important festival" } & \text { [AMI-TXT-LIS-o84] }\end{array}$

$\begin{array}{llllll}\text { Tanu } & \text { lusaq } & \text { sa } & \text { k-ami } & \text { a } & \text { ta-tusa } \\ \text { RESTR.FOC } & \text { cry } & \text { QUOT } & \text { NOM-1P.EXC } & \text { LNK } & \text { CA.RDP-two }\end{array}$
"We two kept crying." [AMI-TXT-CAB-O41]

(a)

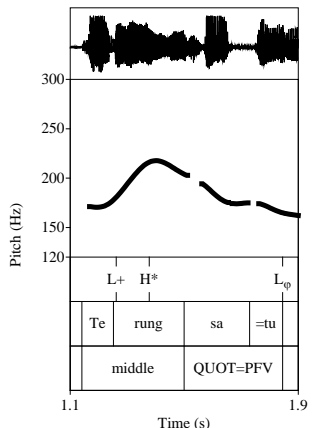

(b)

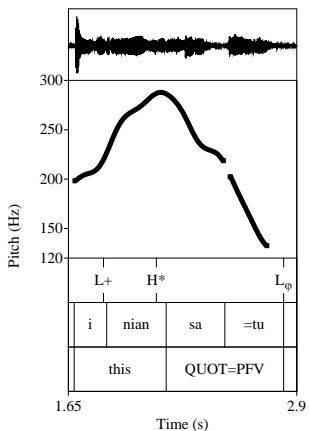

(c)

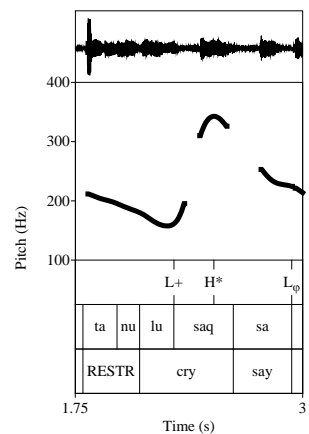

Figure 6: $\quad$ Focus markers

The same prosodic pattern applies to verb focus under the scope of the focus marker han $(=t u)$; see glosses and translation in $(25 \mathrm{a})$ [AMI-TXT-CABo38].

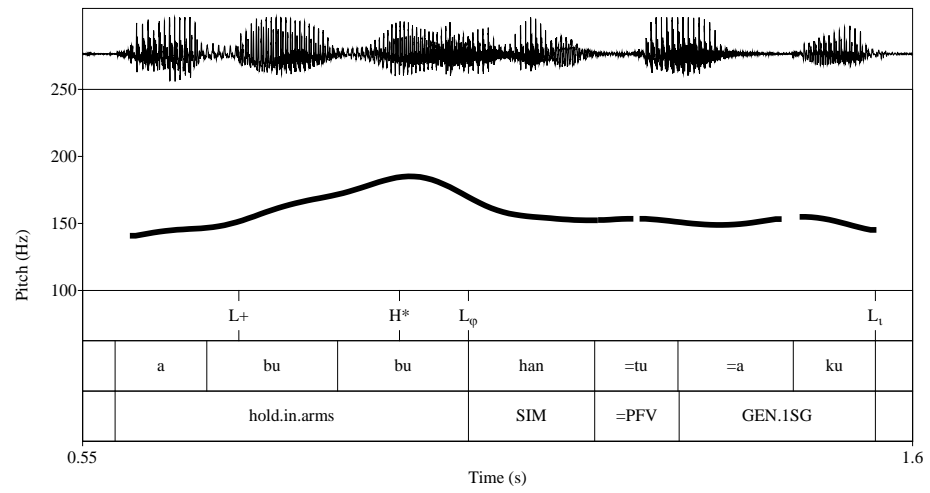

Figure 7: $\quad F_{\mathrm{o}}$ excursion of verb focus with the focus marker han "SIM"

\subsection{Emphatic lengthening}

Emphatic lengthening is a primarily prosodic strategy to draw attention to a part of the utterance, which is often applied to foci (see Rialland \& Robert 2011:912-914 for a similar strategy in Wolof). Emphatic lengthening consists in (a) lengthening the stressed syllable, and (b) frequently shifting the word stress to the penultimate; see Section $3 \cdot 3$.

The prosody of this construction is illustrated by the emphatic verb form in (36); see Figure 8a. The stress is shifted to the penultimate, which is 4.5 times 
longer than the average duration of the further syllables in the same intonational phrase. ${ }^{13}$ The $F_{\mathrm{o}}$ excursion begins a sharp rise before the stressed syllable reaching a high target within the stressed syllable. This bi-tonal event has the same phonetic properties as the sharp rise that was introduced with foci in Sections 4.2 and 4.3. Hence, we adopt the same description as $\mathrm{L}+\mathrm{H}^{*}$, whereby the $\mathrm{H}$-target is associated with the stress $\left({ }^{*}\right)$ and the leading L-target precedes it. The lengthened syllable is realized as a high plateau, while the final syllable displays the default falling contour at the right edge of the phonological phrase, $\mathrm{H}_{\varphi} \mathrm{L}_{\varphi}$. Hence, stress shift helps us disentangle two events that are confounded in foci on oxytone words: the sharp rise at the onset of the stress $\left(\mathrm{L}+\mathrm{H}^{*}\right)$ and the fall associated with the right edge of a $\varphi$-phrase $\left(\mathrm{H}_{\varphi} \mathrm{L}_{\varphi}\right)$.

$$
\begin{array}{lccc}
\text { Niká ci } & \text { Bulád, ci } & \text { ka-ta-tú:dung. } \\
\text { but PM } & \text { Moon } & \text { NEG } & \text { STAT-CA.RDP-apt } \\
\text { "But as for Moon, he is really UNSUITABLE (for this)." [AMI-ELI-o18-1076] }
\end{array}
$$

We also find instances of emphatic lengthening that are performed with modal voice, as shown in Figure 8b. The lengthened syllable is 5.9 times longer than the average of the further syllables. ${ }^{14}$ The realization shows the prototypical properties of creaky voice (Keating et al. 2015). The first half of the vocal fry is a-periodic; the $F_{\mathrm{o}}$ signal is irregular and low, and the glottal constriction is reflected in long closed phases accompanied by small peak glottal openings, as can be seen in the waveform. The rising contour of foci does not apply in these cases.

$\begin{array}{lllllll}\text { (37) Ira } & \text { k-iyaán [...] } & \text { u } & \text { tataá::ng-áy } & \text { a } & \text { qunér } & \text { háw. } \\ \text { EXS } & \text { NOM-ANAPH } & \text { NM } & \text { huge-MODF } & \text { LNK } & \text { snake } & \text { DISC } \\ \text { "There was this HUGE snake...” } & \text { [AMI-TXT-UNI-oo5, oo:00:30] }\end{array}$

(a) High plateau

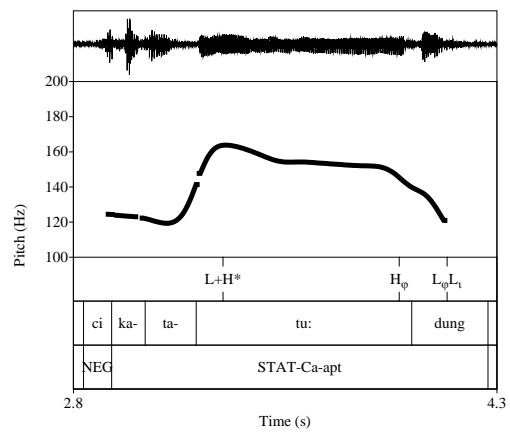

Figure 8: $\quad$ Emphatic lengthening (b) Creaky voice

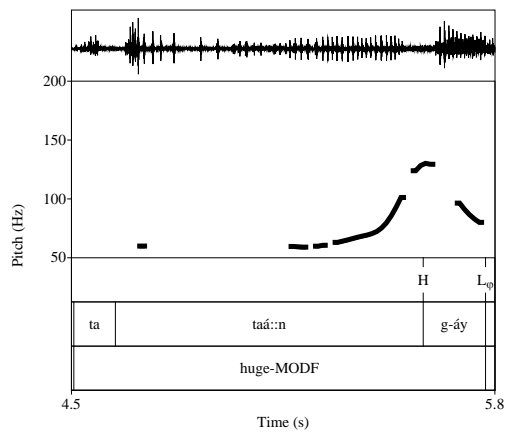

${ }^{13}$ Durations of non-lengthened syllables: ci $100 \mathrm{msec}, k a$ - $119 \mathrm{msec}, t a-181 \mathrm{msec}$, dung 270, msec; Average 167,5 msec. Duration of lengthened syllable: $t u ́$ : $763 \mathrm{msec}$.

${ }^{14}$ Durations of non-lengthened syllables: $t a 127 \mathrm{msec}$, g-ay $191 \mathrm{msec}$; average $159 \mathrm{msec}$. Duration of lengthened syllable: táa::n 945 msec. 
Several means of focus marking can be cumulatively used; see (38): stress shift to the penultimate, lengthening, and CVCV reduplication of the verb patáy "die" yielding a focused verb ma-pata|pá:tay. Figure ga shows the prosodic realization of (38), which has the same properties as the previous examples. A rising contour follows the onset of the penultimate that is clearly lengthened (256 msec, 1.8 times longer than the previous instance of the same syllable in the reduplicated verb, which is $138 \mathrm{msec}$ long). The final syllable of the verb bears a falling contour.

(38) Context: "It was this guy, his disease was spasmodic asthma, he went to the hospital to see a doctor, he stayed a long time at the hospital..."

$\begin{array}{lllll}\text { Yu a=ma-patapá:tay } & \text { cirá } & \text { irí, } \quad . . \\ \text { when FUT=NAV-RDP.die } & \text { NOM.3SG } & \text { TOP } \\ \text { "When he was about to DIE, ..." } & \text { [AMI-TXT-CAB-o26, oo:o2:15] }\end{array}$

Similarly, emphatic lengthening may apply to the narrow focus of cleft constructions; see example (39) and Figure $9 \mathrm{~b}$. The stress is shifted to the penultimate syllable, and the prosodic realization comprises two tonal events: a rise around the onset of the stressed syllable $\left(\mathrm{L}+\mathrm{H}^{*}\right)$ and a fall at the right edge of the phonological phrase $\left(\mathrm{H}_{\varphi} \mathrm{L}_{\varphi}\right)$. Both examples of emphatic lengthening show the characteristic high plateau in the stressed syllable; see Figure 9.

(39) - "Who sewed that dress?"

$\begin{array}{lllll}\mathrm{Na}=\text { akú:=tú } & \text { k-ú } & \text { mi-tais-áy } & \text { t-iyá } & \text { budúy. } \\ \text { PAST=FR.1SG=PFV } & \text { NOM-NM } & \text { AV-sew-NMZ } & \text { OBL-ANAPH } & \text { clothes } \\ \text { "It was me MYSELF who sewed those clothes." [AMI-ELI-o18-1039] } & \end{array}$

(a) Emphatic lengthening and reduplication

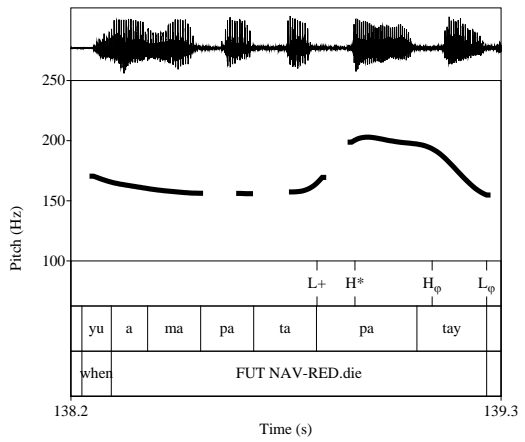

(b) Emphatic lengthening and cleft

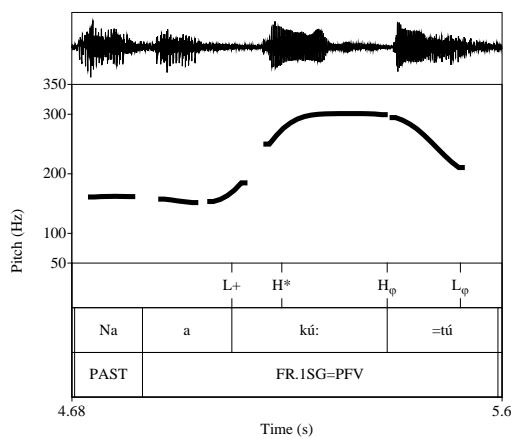

Figure 9: Cumulative use of diverse focus devices

\section{Conclusions}

Three major strategies are used for the expression of focus in Amis. Cleft constructions are a very productive means that involves an initial focus and a nominalized clause. These constructions are associated with syntactic restructuring, since the initial focus is accompanied with a change of the 
syntactic pivot (and the selection of voice accordingly). Furthermore, Amis has some morphological markers that attach to the focus. These elements are not associated with any change of word order or syntactic relations, they just determine the focus domain. Finally, Amis makes use of lengthening, a particular prosodic strategy for the expression of emphasis, which very often applies to foci (without being restricted to foci).

The present study examines the $F_{\circ}$ excursions of these constructions based on corpus and elicited examples. A pervasive property of the Amis intonation is that phonological phrases are enclosed with a falling contour, which we analyzed as a phrase tone $\left(\mathrm{H}_{\varphi} \mathrm{L}_{\varphi}\right)$. This contour appears - among else - at the right edge of initial predicates and at the right edge of the clefted constituents in neutral contexts. Narrow focus differs in that it is realized with a sharp rise around the onset of the stressed syllable $\left(\mathrm{L}+\mathrm{H}^{*}\right)$. This event is found in all constructions involving focus, i.e., in cleft constructions, in focus constructions with a focus particle and in emphatic lengthening. We conclude that this prosodic event is associated with focus.

In terms of a typological evaluation, the prosodic pattern we report for Amis $\varphi$-phrases differs from the prosodic facts that are known for the wellstudied languages with oxytone words, i.e., Turkish and French. The default realization of $\varphi$-phrases in these languages are rising contours that are realized within the final syllable; see Turkish in Kamali (2011:72) and French in Féry (2017:273-277). By contrast in Amis, $\varphi$-phrases are bounded by a falling contour, which is realized within the final syllable of the prosodic constituent (which coincides with the stress in most cases).

The prosody of foci shows three properties that are cross-linguistically recurrent. First, clause-initial foci are prosodically integrated with the predicate, while topic constituents form a prosodic constituent on their own. This contrast is reported for many V-initial languages; e.g., Gela (Austronesian; Simard \& Wegener 2017:21), Hungarian (Finno-ugric; Szendrői 2003:46), Yucatec Maya (Mayan; Verhoeven \& Skopeteas 2015:34). Second, narrow focus is signaled by a sharp rise. An $\mathrm{L}+\mathrm{H}^{*}$ bitonal event is associated with focus in several languages, e.g., in Greek (Arvaniti \& Baltazani 2005:113), Italian (Grice et al. 2005:364) or Bininj Gun-wok (Gunwinyguan/Australia; Bishop \& Fletcher 2005:348). Third, Amis displays postfocal de-accenting. We know that languages differ with respect to the use of postfocal de-accenting (see Gussenhoven 2004:275). Our data are particularly interesting since Amis (Austronesian) is spoken in an area in which postfocal deaccenting is weakly represented (see $\mathrm{Xu} 2011$ on an evolutionary scenario about East Asian languages; see also Xu et al. 2012 on Taiwanese).

\section{References}

Arvaniti A. \& Baltazani M., 2005, Intonational analysis and prosodic annotation of Greek spoken corpora, in Jun Sun-Ah (ed.), Prosodic typology: The phonology of intonation and phrasing, Oxford, Oxford University Press, p. 84-117.

Bishop J. \& Fletcher J., 2005, Intonation in six dialects of Bininj Gun-wok, in Jun SunAh (ed.), Prosodic typology: The phonology of intonation and phrasing, Oxford, Oxford University Press, p. 331-361.

Bril I., 2016, Information structure in Northern-Amis (Formosan): A morphosyntactic analysis, Oceanic Linguistics 55(2), p. 451-481. 
Bril I., 2017, Roots and stems: Lexical and functional flexibility in Amis and Nêlêmwa, Studies in Language. Special issue on lexical flexibility in Oceanic languages 41(2), ed. by Eva van Lier, p. 358-407.

Chen T., 1987, Verbal constructions and verbal classifications in Nataoran Amis, Canberra, Pacific Linguistics.

Edmonson J., Esling J., Harris J. \& Huang T.-Ch., 2005, A laryngoscopic study of glottal and epiglottal/pharyngeal stop and continuant articulations in Amis-an Austronesian language of Taiwan, Language and Linguistics 6(3), p. 381-396.

Féry C., 2017, Intonation and prosodic structure, Oxford, Oxford University Press.

Grice M., D'Imperio M., Savino M. \& Avesani C., 2005, Strategies for intonation labelling across varieties of Italian, in Jun Sun-Ah (ed.), Prosodic typology: The phonology of intonation and phrasing, Oxford, Oxford University Press, p. 362-389.

Gussenhoven C., 2004, The phonology of tone and intonation, Cambridge, Cambridge University Press.

Kamali B., 2011, Topics at the PF interface of Turkish, PhD dissertation, Harvard University.

Keating P., Garellek M. \& Jody Kreiman J., 2015. Acoustic properties of different kinds of creaky voice, ICPhS 2015, 18th International Congress of Phonetic Sciences, Proceedings.

Keenan E., \& Comrie B., 1977, Noun phrase accessibility and universal grammar, Linguistic Inquiry 8, p. 63-99.

Keenan E., \& Comrie B., 1979, Data on the noun phrase accessibility hierarchy, Language 55, p. 333-51.

Krifka M., 2007, Basic notions of information structure, in C. Féry, G. Fanselow \& M. Krifka (eds.), The notions of information structure, Potsdam, Universitätsverlag, p. $13-55$.

Ladd R. D., 2008, Intonational phonology, Cambridge, Cambridge University Press.

Lambrecht K., 1994, Information structure and sentence form: Topic, focus, and the mental representations of discourse referents, Cambridge, Cambridge University Press.

Pierrehumbert J. B., 1980, The phonology and phonetics of English intonation, $\mathrm{PhD}$ dissertation, MIT

Rialland A. \& Stéphane Robert S., 2001, The intonational system of Wolof, Linguistics 39(5), p. 893-939.

Selkirk E., 2011, The syntax-phonology interface, in John Goldsmith, Jason Riggle and Alan Yu, The handbook of phonological theory, Oxford, Blackwell, p. 435-484.

Simard C. \& Wegener C., 2017, Fronted NPs in a verb-initial language - clauseinternal or external? Prosodic cues to the rescue!, Glossa 2(1), p. 1-32.

Szendrői K., 2003, A stress-based approach to the syntax of Hungarian focus, The Linguistic Review 20, p. 37-78.

Van Valin R. D., 2005, Exploring the syntax-semantics interface, Cambridge, Cambridge University Press.

Verhoeven E. \& Skopeteas S., 2015, Licensing focus constructions in Yucatec Maya, International Journal of American Linguistics 81(1), p. 1-40.

Wolff J. U., 1973, Verbal inflection in Proto-Austronesian, in A. B. Gonzalez (ed.), Parangal kay Cecilio Lopez: Essays in honor of Cecilio Lopez on his seventy-fifth birthday, LSP Special monograph Issue $\mathrm{n}^{\circ} 4$, Quezon City, Linguistic Society of the Philippines, p. 71-91.

$\mathrm{Xu} \mathrm{Yi,} \mathrm{2011,} \mathrm{Post-focus} \mathrm{compression:} \mathrm{Cross-linguistic} \mathrm{distribution} \mathrm{and} \mathrm{historical} \mathrm{origin,}$ in Proceedings of the 17th International Congress of Phonetic Sciences, Hong Kong, p. 152-155.

Xu Yi, Szu-wei Chen \& Bei Wang, 2012, Prosodic focus with and without post-focus compression: A typological divide within the same language family?, The Linguistic Review 29, p. 131-147. 